\title{
Migratory destinations of humpback whales that feed off California, Oregon and Washington
}

\author{
John Calambokidis ${ }^{1, *}$, Gretchen H. Steiger ${ }^{1}$, Kristin Rasmussen ${ }^{1}$, Jorge Urbán R. ${ }^{2}$, \\ Kenneth C. Balcomb ${ }^{3}$, Paloma Ladrón de Guevara P. ${ }^{4}$, Mario Salinas Z. ${ }^{4}$, \\ Jeff K. Jacobsen ${ }^{5}$, C. Scott Baker ${ }^{6, * *}$, Louis M. Herman ${ }^{6}$, Salvatore Cerchio ${ }^{7, * * *}$, \\ James D. Darling ${ }^{8}$
}

\footnotetext{
${ }^{1}$ Cascadia Research Collective, Waterstreet Building, 2181/2 West Fourth Avenue, Olympia, Washington 98501, USA ${ }^{2}$ Departamento de Biología Marina, Universidad Autónoma de Baja California Sur, Apt. Post 19-B, B.C.S. 23081, Mexico

${ }^{3}$ Center for Whale Research, 1359 Smuggler's Cove Road, Friday Harbor, Washington 98250, USA

${ }^{4}$ Laboratorio de Mamiferos Marinos, Universidad Nacional Autónoma de México, Apt. Post 70-572, México City, D.F. 04510, Mexico
}

${ }^{5}$ PO Box 4492, Arcata, California 95521, USA

${ }^{6}$ Kewalo Basin Marine Mammal Laboratory, University of Hawaii, 1129 Ala Moana Blvd., Honolulu, Hawaii 96814, USA

${ }^{7}$ Moss Landing Marine Laboratories, PO Box 450, Moss Landing, California 95039, USA

\begin{abstract}
The migratory destinations of humpback whales that feed off California. Oregon and Washington were determined using photo-identification. Fluke photographs of 594 individuals were taken between 1981 and 1992 and compared to collections from 9 wintering regions in the North Pacific: Ogasawara (162) and Okinawa (17) islands of Japan the Big Island and Maui (634 for both) and Kauai (384) of Hawaii; the Revillagigedo Archipelago (450), the mainland coast (383) and Baja Peninsula (471) of Mexico; and Central America (31). A total of 160 matches were found to 6 central and eastern North Pacific wintering regions, with most from Central America, Baja, and mainland Mexico. Of whales identified off Central America, $84 \%$ were resighted off California-Washington; this high rate of interchange suggests that whales in these tropical waters appear to be comprised entirely of animals from the California-Washington feeding aggregation. Humpback whales seen off Central America were resighted disproportionately off southern California while those from mainland Mexico tended to be seen off northern California-Washington. From 157 same-season migratory transits documented, the shortest were $29 \mathrm{~d}$ to Baja and $56 \mathrm{~d}$ to Costa Rica and the longest distance was $5322 \mathrm{~km}$. Of the California-Washington whales with known sex, the proportion of males identified at a wintering region was significantly higher than females $(2.2: 1, \mathrm{p}<0.05)$.
\end{abstract}

KEY WORDS: Humpback whales · Migration · Photo-identification · North Pacific

\section{INTRODUCTION}

•E-mail: calambokidis@cascadiaresearch.org

Present addresses:

- School of Biological Sciences, University of Auckland Private Bag 92019, Auckland, New Zealand

-.Univ. of Michigan, 1109 Geddes Avenue, Ann Arbor, Michigan 48109, USA
Humpback whales Megaptera novaeangliae undergo the longest migration documented for any mammal (Stone et al. 1990). Their movement patterns between summer feeding areas at high latitudes and winter mating and calving areas at low latitudes have been 
the subject of research in a number of regions. In the North Atlantic, defining these migratory movements and the resulting stock structure has been relatively straightforward due to the existence of a single primary wintering area (Palsboll et al. 1997, Smith et al. 1999) Defining the stock structure of humpback whales in the North Pacific has proven to be more complicated due to the existence of both multiple summer feeding and winter breeding areas. At least 4 wintering areas have been described: (1) the waters of $\mathrm{Mex}$ ico (mainland Mexico, Baja California and the Revillagigedo Archipelago) (Urbán \& Aguayo 1987, Alvarez et al. 1990), (2) Costa Rica (Steiger et al. 1991, Acevado \& Smultea 1995, Rasmussen et al. 1995), (3) the Hawaiian Islands (Herman \& Antinoja 1977) and (4) islands of Japan (Nishiwaki 1959, Darling \& Mori 1993, Uchida et al. 1993).

Although the number and boundaries of the feeding grounds for humpback whales in the North Pacific have not been fully described, the range of one major feeding aggregation of California, Oregon and Washington has been well defined. Whales in this region were first thought to be en route to feeding grounds off Alaska (Kellogg 1929, Tomilin 1957), but more recently photo-identification studies (Calambokidis et al. 1996) and mtDNA studies (Baker et al. 1990, 1998) suggest that whales from this area constitute a separate feeding aggregation. This feeding ground ranges between 32 and $48^{\circ} \mathrm{N}$, with the main concentration inhabiting Californian waters between 32 and $39^{\circ} \mathrm{N}$ (Calambokidis et al. 1996). The abundance of this subpopulation in the early 1990s was estimated at about 600 whales and appears to be increasing (Barlow 1994, 1995, Calambokidis \& Steiger 1995).

While migratory destinations of humpback whales that feed off Alaska and British Columbia have been reported (Darling \& Jurasz 1983, Darling \& McSweeney 1985, Baker et al. 1986, Darling \& Cerchio 1993, Darling et al. 1996, Gabrielle et al. 1996), very little information has been published on the migratory destinations of the humpback whales that feed off $\mathrm{Cal}$ ifornia, Oregon and Washington. Baker et al. (1986) reported resightings of a single whale between California and mainland Mexico and a second whale between California and Hawaii, but this was based on a sample of only 18 whales from California. Preliminary results of movements between California and Mexico from a small sub-sample labout 100 identifications of the sample used in this study wore reported by Urbain et al. (1987). Steiger et al. (1991) reported the first documented migrations of 3 whales between $\mathrm{Cal}$ ifornia and Costa Rica.

We examine several aspects of the migratory destinations of humpback whales of this major feeding aggregation. We provide the first quantitative analysis of migratory destinations of these animals using a comprehensive collection of identified individuals and examine the evidence for stratification in these destinations related to distribution within a single feeding aggregation. We also document the fastest transit times of whales to some of these destinations and differences in migratory rates by sex.

\section{METHODS}

Collections of humpback whale fluke photographs were assembled from independent researchers working throughout the North Pacific and were compared visually at Cascadia Research Collective (CRC). Natural markings on the ventral side of the fluke were used to identify them as described previously (Katona et al. 1979). Photographs of whales taken off California, Oregon and Washington were compared with 7 independent collections from 9 wintering regions in the North Pacific (Fig 1). Sample sizes shown are photographs judged to be of suitable quality for comparison.

California, Oregon and Washington. Because this sample was collected predominantly off California, it will be referred to as the 'Calıfornia' sample. A sample of 594 individuals identified between 1981 and 1992 was used in the comparison to the wintering regions. A larger sample was used (897 unique whales identified through 1997, inclusive of the first sample used here) in the comparison of whales identified off Central America and to examine transit times (see below).

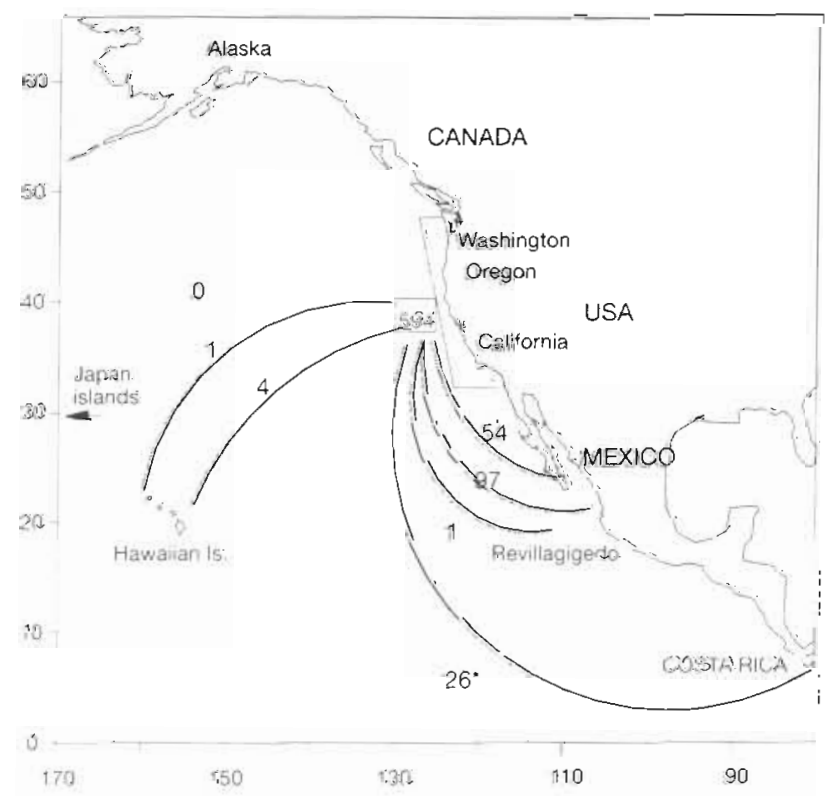

Fig. 1 Migratory destinations of humpback whales seen off California between 1981 and 1992. "Includes data through 1997 for Costa Rica 
Photographs were taken by CRC, the Center for Whale Research (CWR), Friday Harbor, Washington, and other collaborators during humpback and blue whale photo-identification studies (Table 1; Calambokidis et al. 1990, 1996). Research was conducted in waters out to about $60 \mathrm{~km}$ off central California between 1986 and 1990 and was expanded to include surveys along the entire California coast beginning in 1991. Whales identified along the Washington/British Columbia border were not included in this analysis, because they appear to be from a separate feeding aggregation that extends northward and is largely distinct from the aggregation feeding off California, Oregon and Washington (Calambokidis et al. 1996).

The vessels included 4 to $6 \mathrm{~m}$ inflatable boats. Photographs were taken with Nikon motor-advance $35 \mathrm{~mm}$ SLR cameras with $300 \mathrm{~mm} \mathrm{f4.5}$ lenses with Ilford HP-5 or Kodak Tri-X black-and-white negative film. Shutter speeds were usually $1 / 1000 \mathrm{~s}$ or faster. Film was exposed at ISO 1200 and development times were adjusted accordingly.

Mainland Mexico. Photographs were taken in the waters of Bahía de Banderas and the areas near Islas Tres Marías and Isabel. This collection was maintained by the Universidad Nacional Autonoma de México (UNAM) (Ladrón de Guevara P. 1995). This region is described by Urbán \& Aguayo (1987).

Baja California, Mexico. Whales were identified off the southern coast of Baja California. Data were col-

Table 1. Summary of effort made to photo-identify humpback whales off California, Oregon and Washington. The 594 unique whales photographed from 1981 to 1992 were used in the comparison to all wintering regions except Costa Rica, for which the 1981 to 1997 sample of 897 whales was used

\begin{tabular}{|lccc|}
\hline Year & Dates & $\begin{array}{c}\text { No. of } \\
\text { surveys }\end{array}$ & $\begin{array}{c}\text { No. of whales } \\
\text { identified }\end{array}$ \\
\hline $1981-1985$ & 4 May-30 Nov & $\circ$ & 20 \\
1986 & 23 Jul-15 Sep & 71 & 91 \\
1987 & 17 Aug-17 Oct & 58 & 150 \\
1988 & 19 Aug-2 Nov & 66 & 213 \\
1989 & 8 Sep-26 Oct & 15 & 110 \\
1990 & 4 Sep-13 Nov & 29 & 208 \\
1991 & 16 Jul-15 Nov & 53 & 269 \\
1992 & 24 May-16 Nov & 73 & 398 \\
1993 & 28 Jul-22 Oct & 48 & 254 \\
1994 & 15 Jun-10 Oct & 51 & 260 \\
1995 & 10 Jun-3 Dec & 60 & 363 \\
1996 & 21 Apr-12 Nov & 129 & 364 \\
1997 & 21 Feb-5 Nov & 150 & 286 \\
Total & & 803 & 2986 \\
Unique whales, 1981-1992 & & 594 \\
Unique whales, 1981-1997 & & 897 \\
aOpportunistic surveys; photos were contributed by other \\
researchers
\end{tabular}

lected by the Universidad Autonoma de Baja California Sur (UABCS) and CWR.

Revillagigedo Archipelago. This sample was collected in a collaborative effort. This archipelago is about $450 \mathrm{~km}$ southwest of Cabo San Lucas and includes Islas Socorro, San Benedicto and Clarion (Urbán \& Aguayo 1987). Most survey effort was made at Isla Socorro.

Costa Rica/Panama. Most of the photo-identification data from Costa Rica has come from surveys since 1996. Because of the small sample from the period addressed here, we have included a more recent comparison of 31 humpback whales photographed off Costa Rica between 1988 and 1998. To make the comparison contemporaneous, we used whales identified off California through 1997 (965). Most of these surveys were conducted off southwestern Costa Rica along the Osa Peninsula by CRC in January and February (Calambokidis 1997). A photograph of a single whale from the Gulf of Panama on 5 January 1996 was provided by Jack Swenson.

Big Island and Maui, Hawaii. A catalog of whales identified in Hawaiian waters was provided by the Kewalo Basin Marine Mammal Laboratory at the University of Hawaii (Baker et al. 1986, Perry et al. 1988, 1990) and published as a catalog by Perry et al. (1988). Photographs were primarily taken off the leeward coasts of the Big Island and west Maui.

Kauai, Hawaii. The study region encompassed the south and west coasts from Makahuena Point and Makaha Point (Cerchio 1998).

Japan. A catalog of humpback whales was used of whales off Ogasawara and Okinawa (Darling \& Mori 1993) that was published by Darling (1991).

Analysis. Migratory transit times between wintering regions and feeding areas in one season were examined. All sightings of the same individual whale off California and in a wintering region within a 1 yr period were compiled to evaluate minimum transit intervals. Because of the incomplete sampling effort, these times are not necessarily representative of the true transit times. Distances between locations where whales were sighted were calculated based on Great Circle routes without adjustment for possible deviations to avoid landmasses or follow likely migration routes. They therefore represent minimum distances.

We examined the migration destinations of whales for which sex was known. To avoid biases, we only included whales that were sexed based on evidence (i.e. molecular or behavioral) from the feeding ground from 1987 to 1992 (Baker et al. 1991, 1998).

Our sample was stratified by sub-area to examine differences in migratory destinations within the feeding ground. The occurrence of whales in 3 sub-areas was determined: (1) southern California, from the 
Table 2. Summary of the matches found among humpback whales identıfied off California, Oregon and Washington between 1981 and 1992 (1997 for Costa Rica) and those photographed at the North Pacific breeding grounds. UNAM: Universidad Nacional autónoma de México; UABCS: Universidad Autónoma de Baja California Sur; CWR: Center for Whale Research; CRC: Cascadia Research Collective

\begin{tabular}{|c|c|c|c|c|c|}
\hline Region & Primary data source & Years & $\begin{array}{c}\text { No. of } \\
\text { individuals }\end{array}$ & $\begin{array}{c}\text { Matches } \\
\text { Number }\end{array}$ & $\begin{array}{l}\text { R/WA } \\
\%\end{array}$ \\
\hline \multicolumn{6}{|l|}{ Mexico } \\
\hline Revillagigedos Archipelago & UNAM \& Jacobsen & $1986-1992$ & 450 & 1 & 0.2 \\
\hline Baja California & UABCS \& CWR & $1987-1993$ & 471 & 54 & 11 \\
\hline Mainland Mexico & UNAM & $1983-1992$ & 383 & 97 & 25 \\
\hline Total for Mexico & & & 1190 & 130 & 11 \\
\hline \multicolumn{6}{|l|}{ Central America } \\
\hline $\begin{array}{l}\text { Hawaii } \\
\text { Big Island/Maui } \\
\text { Kauai }\end{array}$ & $\begin{array}{c}\text { Perly et al. }(1988)^{b} \\
\text { S. Cerchio }\end{array}$ & $\begin{array}{l}1977-1985 \\
1989-1991\end{array}$ & $\begin{array}{l}634 \\
384\end{array}$ & $\begin{array}{l}4 \\
1\end{array}$ & $\begin{array}{l}0.6 \\
0.34\end{array}$ \\
\hline $\begin{array}{l}\text { Japan } \\
\text { Ogasawara } \\
\text { Okunawa }\end{array}$ & $\begin{array}{l}\text { Darling }(1991)^{\mathrm{C}} \\
\text { Darling }(1991)^{\mathrm{C}}\end{array}$ & $\begin{array}{l}1987-1990 \\
1989-1990\end{array}$ & $\begin{array}{r}162 \\
18\end{array}$ & $\begin{array}{l}0 \\
0\end{array}$ & $\begin{array}{l}0 \\
0\end{array}$ \\
\hline \multicolumn{6}{|c|}{$\begin{array}{l}\text { "This comparison included } 897 \text { whales identified off California, Oregon and Washington between } 1981 \text { and } 1997 \\
\text { "Catalog published by Kewalo Basin Marine Manual Laboratory } \\
\text { "Catalog published by West Coast Whale Research Foundation } \\
\text { "Same whale also seen of Big lsland/Maui }\end{array}$} \\
\hline
\end{tabular}

Mexican border $\left(32^{\circ} 35^{\prime} \mathrm{N}\right)$ to Point Sur $\left(36^{\circ} 20^{\prime} \mathrm{N}\right)$, (2) central California, from Point Sur $\left(36^{\circ} 20^{\prime} \mathrm{N}\right)$ to Point Arena $\left(39^{\circ} 00^{\prime} \mathrm{N}\right)$, encompassing the 2 primary areas in which effort was made, the Farallon Is./Cordell Bank region and Monterey Bay, and (3) northern waters, including northern California, Oregon and Washington $\left(39^{\circ} 00^{\prime}\right.$ to $\left.48^{\circ} 00^{\prime} \mathrm{N}\right)$. The proportion of whales and the number of years individuals were seen in these 3 sub-areas were averaged and then compared among the individuals with known winter migratory destinations and those for which the destinations were unknown.

\section{RESULTS}

\section{Migratory destinations}

A total of 160 humpback whales were matched between California and a wintering region (Table 2). The proportion of whales identified in different wintering regions that had also been seen off California varied significantly by location $\left(\chi^{2}=538, p<0.001\right)$. The largest number of matches (and highest proportion of whilcm from California were found on the wintering grounds of Central America, mainland Mexico and Baja California (Table 2). The largest number of matches was to mainland Mexico and Baja. Of the whales photographed off mainland Mexico, $25 \%$ were from Californid, just over twice that found off Baja $(11 \%)$. Although the number of matches was lower (due to sample size), the percentage of humpback whales identified off Central America in winter that were also sighted off California (84\%) was higher than any other region

Movement of whales between California and other wintering regions was rare $(<1 \%$, Table 2$)$. In our sample, 4 whales were documented to have migrated between California and Hawail at least once (Table 3). One of these (CRC 10144) was determined to be a mature female when it was accompanied by a calf off California in 1988. CRC 10093 was photographed by Marc Webber off California in 1981, and was then also sighted of Hawaii in 1982 and Kauai in 1989. This whale has not been resighted off California since 1981 Only 1 whale (CRC 10010) moved between California and the Revillagigedo Archipelago (Table 3) No interchange was observed between whales off California and those photographed off Japan.

\section{Migratory transits}

We documented 157 migratory transits (same season of whales between California and several wintering regions (Table 4). Because longer transit intervals could be an artifact of sampling effort, we focused on the shortest intervals documented. The shortest transit time was to southern Baja California in $29 \mathrm{~d}(1900 \mathrm{~km}$, CRC 9508); the fastest time to mainland Mexico was $39 \mathrm{~d}(2589 \mathrm{~km}, \mathrm{CRC} 10020)$ and to Costa Rica was $56 \mathrm{~d}$ $15097 \mathrm{~km}$, CRC 9031). The fastest record of swimming 
Table 3. Records of individual humpback whales from California with unusual migratory destinations through 1992 Identification numbers of the contributing organizations and catalogs are given

\begin{tabular}{|c|c|}
\hline Year & Region \\
\hline \multicolumn{2}{|c|}{ CRC 9021/KBMML 1000} \\
\hline 1982 & Hawaii \\
\hline 1988 & Califomia-Pt San Luis \\
\hline 1991 & Califomia-Pt San Luis \\
\hline 1992 & Califomia-Santa Barbara \\
\hline \multicolumn{2}{|c|}{ CRC $10093 / \mathrm{KBMML} 1103 / \mathrm{SC}-012^{\mathrm{a}}$} \\
\hline 1981 & Califomia-Gulf of Farallones ${ }^{b}$ \\
\hline 1982 & Hawaii \\
\hline 1989 & Hawaii-Kauai \\
\hline \multicolumn{2}{|c|}{ CRC $10130 / \mathrm{KBMML} 1084$} \\
\hline 1982 & Hawaii \\
\hline 1987 & Califomia-Gulf of the Farallones \\
\hline 1988 & Califomia-Gulf of the Farallones \\
\hline 1989 & Califomia-Gulf of the Farallones \\
\hline 1990 & Califomia-Gulf of the Farallones \\
\hline 1992 & Califomia-Pt Arena and Fort Bragg \\
\hline \multicolumn{2}{|c|}{ CRC 10144/KBMML 231} \\
\hline 1980 & Hawaii \\
\hline 1987 & Califomia-Gulf of the Farallones \\
\hline 1988 & Califomia-Gulf of the Farallones ${ }^{c}$ \\
\hline 1992 & Califomia-Gulf of the Farallones/Pt Arena \\
\hline \multicolumn{2}{|c|}{ CRC 10010/UNAM 2A 191R053 UABC5 589/JJ004 } \\
\hline 1986 & Califomia-Gulf of the Farallones \\
\hline 1990 & Califomia-Gulf of the Farallones \\
\hline 1991 & Revillagigedos Archipelago \\
\hline 1991 & Califomia-Pt St George \\
\hline 1992 & Califomia-Santa Barbara Channel \\
\hline \multicolumn{2}{|c|}{ Reported by Baker et al. (1986) } \\
\hline \multicolumn{2}{|c|}{ bPhotographed by Marc Webber } \\
\hline \multicolumn{2}{|c|}{ "Seen with a calf } \\
\hline
\end{tabular}

speed was $3.8 \mathrm{~km} \mathrm{~h}^{-1}$ between California and Costa Rica (assuming the whale was swimming on a direct route $24 \mathrm{~h} \mathrm{~d}^{-1}$ ). Fastest speeds to both Baja California and mainland Mexico were $2.7 \mathrm{~km} \mathrm{~h}^{-1}$. These maximal distances and speeds are minimums because whales probably moved more extensively or in shorter periods than we documented. The farthest straight-line distance traveled was $5322 \mathrm{~km}$ (northern California to Costa Rica, CRC 10583).

\section{Feeding area occupancy and annual return by wintering region}

The number of years and times per year individual whales were sighted off California did not vary greatly and were not significantly different among the whales with different known migratory destinations (Table 5). Whales known to migrate to Hawaii and the Revil- lagigedos Archipelago had somewhat outlying values, although sample sizes were too small to test statistically. The average number of years that whales were sighted off California did not vary significantly between those known to migrate to Hawaii, mainland Mexico, Baja California, and Central America (ANOVA, $F=1.07, \mathrm{p}>0.05$ ). These values were slightly higher, however, than for whales for which winter migratory destinations were not known (Table 5).

\section{Migratory destinations by sub-area}

Whales from some wintering regions were more likely than others to be sighted in 1 of 3 sub-areas within the feeding ground (Table 5). Of whales with the known migratory destinations of Central America, mainland Mexico, and Baja California, there were significant differences in the proportion that were seen off southern California $\left(\chi^{2}=20.4, p<0.01\right)$ and northern waters $\left(\chi^{2}=4.9 \mathrm{p}<0.05\right)$. Whales known to migrate to Central America were 3 times more likely to be seen in southern California ( 63 vs $21 \%$ ) and less than half as likely to be seen in northern waters ( 22 vs $46 \%$ ) than those from mainland Mexico. Whales that had been seen off Baja California had a resighting rate in the feeding sub-areas that was intermediate to those for mainland Mexico and Central America. A similar pattern was apparent in the mean number of years whales were seen in these sub-areas when divided among their known wintering regions (Table 5). Whales known to winter off mainland Mexico were seen significantly more years in northern waters (ANOVA, $F=$ 11.6, $\mathrm{p}<0.001$ ) and significantly fewer years off southern California (ANOVA, $F=4.4, \mathrm{p}<0.05$ ) than whales with unknown wintering destinations (Table 5).

\section{Migratory destinations by sex}

Of 69 whales for which the sex was identified off California through 1992, 23 were also sighted on a wintering ground. Known males from California were 2.2 times more likely to have also been identified on a wintering ground than known females $\left(\chi^{2}=5.5, \mathrm{p}<\right.$ $0.05)$. Of 23 whales determined to be males off California, $12(52 \%)$ were identified on a winter ground; of 46 females, only $11(24 \%)$ were identified.

\section{DISCUSSION}

The comparison of more than 2500 identification photographs from all. known wintering grounds in the North Pacific provides strong evidence for preferred 
Table 4. Transit times of humpback whales between California and wintering regions

\begin{tabular}{|c|c|c|c|c|c|c|c|c|c|}
\hline \multirow{2}{*}{ Direction } & \multirow{2}{*}{$\begin{array}{l}\text { No of } \\
\text { transits }\end{array}$} & \multirow[b]{2}{*}{$\begin{array}{c}\text { No. of } \\
\text { days }\end{array}$} & \multirow{2}{*}{\multicolumn{4}{|c|}{$\begin{array}{rr}\text { Shortest transit interval } \\
\text { CRCID CAlocation } \\
\text { Dates seen }\end{array}$}} & \multirow[b]{2}{*}{$\begin{array}{c}\text { No. of } \\
\mathrm{km}\end{array}$} & \multirow[b]{2}{*}{$\begin{array}{c}\text { Speed } \\
\left(\mathrm{km} \mathrm{h} \mathrm{h}^{-1}\right)\end{array}$} & \multirow{2}{*}{$\begin{array}{l}\text { Longest } \\
\text { interval } \\
\text { (no. of days) }\end{array}$} \\
\hline & & & & & & & & & \\
\hline \multicolumn{10}{|c|}{ Baja California } \\
\hline $\mathrm{N}$ & 33 & 29 & 9508 & Pt Sur & $10 \mathrm{Mar} 1990$ & 8 Apr 1990 & 1900 & 2.73 & 313 \\
\hline $\mathrm{S}$ & 22 & 100 & 10563 & Monterey Bay & 15 Nov 1991 & 23 Feb 1992 & 1913 & 0.80 & 234 \\
\hline All & 55 & & & & & & & & \\
\hline \multicolumn{10}{|c|}{ Mainland Mexico } \\
\hline$N$ & 51 & 137 & 12002 & Heceta Bank & 8 Feb 1990 & 25 Jun 1990 & 3152 & 0.96 & 315 \\
\hline $\mathrm{S}$ & 27 & 39 & 10020 & Cordell Bank & $2 \operatorname{Dec} 1990$ & $10 \operatorname{Jan} 1990$ & 2589 & 2.77 & 317 \\
\hline Al] & 78 & & & & & & & & \\
\hline \multicolumn{10}{|c|}{ Revillagigedo Archipelago } \\
\hline$N$ & 1 & 219 & 10010 & Bodega Bay & 23 Jan 1991 & 30 Aug 1991 & 2459 & 0.47 & 219 \\
\hline $\mathrm{s}$ & 1 & 71 & 10010 & Cordell Bank & 13 Nov 1990 & $23 \operatorname{Jan} 1991$ & 2491 & 1.46 & 71 \\
\hline All & 2 & & & & & & & & \\
\hline \multicolumn{10}{|l|}{ Costa Rica } \\
\hline $\mathrm{N}$ & 10 & 69 & 10731 & Half Moon Bay & 12 Feb 1996 & 21 Apr 1996 & 5045 & 3.05 & 254 \\
\hline $\mathrm{S}$ & 10 & 56 & 9031 & Gulf of the Faraliones & 1 Dec 1995 & $26 \operatorname{Jan} 1996$ & 5097 & 3.79 & 233 \\
\hline All & 20 & & & & & & & & \\
\hline \multicolumn{10}{|l|}{ Panama } \\
\hline $\mathrm{S}$ & 1 & 144 & 10593 & San Luis & 14 Aug 1995 & 5 Jan 1996 & 5208 & 1.51 & 144 \\
\hline \multicolumn{10}{|l|}{ Hawaii } \\
\hline$S$ & 1 & 153 & 10093 & Gulf of the Farallones & $30 \mathrm{Jun} 1981$ & 1982 & 3700 & & 153 \\
\hline
\end{tabular}

migratory destinations of humpback whales from the California feeding ground, with the majority of whales traveling to mainland Mexico, Baja California and Central America. These findings are consistent with and extend the previous demographic evidence for stock structure in the North Pacific including the initial reports of the first matches of humpbacks from California to those in wintering areas in Hawaii, Mexico and Costa Rica (Baker et al 1986, Urbán et al. 1987, Steiger et al. 1991).

Among the 3 regions of Mexico, there were dramatic differences in the proportion of whales that were also seen in the California feeding ground; rates were high for both mainland Mexico and Baja California but quite low for the offshore Revillagigedo Archipelago; the proportion of whales that were also seen in the California feeding area was lower here than for the Hawailan Islands. This is consistent with the few limited matches reported in the past between California and Mexico that only involved whales from mainland Mexico (Baker et al. 1986, Urbán et a]. 1987).

In spite of the strong tendencies described here, it is clear that the migratory routes of North Parifir humpbacks do not follow the simple patten whereby all whales of a feeding aggregation travel to a single wintering area. Similar to our findings off California, humpback whales from other North Pacific feeding grounds have been documented traveling to multiple wintering areas: whales from Prince William Sound have been seen off mainland Mexico, the Revillagigedos Archipelago and Hawaii (Baker et al. 1985, 1986. Darling \& McSweeney 19851, and those off British Columbia have been sighted off all Mexican wintering grounds, Hawaii, and Japan (Darling \& McSweeney 1985, Darling et al. 1996).

Our results are consistent with findings from genetics studies. Such studies have demonstrated highly significant differences in mtDNA haplotypes (Baker et al. $1990,1994,1998$ ) and weak but still significant differences in alleles of nuclear microsatellites and the actin intron (Baker et al. 1998) among feeding areas, including California. Additionally, the strong migratory connections between some feeding areas and wintering regions were also reflected in similarities in miDNA haplotypes between California and Mexico as well as some Alaskan feeding grounds and Hawaii. The mtDNA patterns were not identical between these wintering and feeding grounds, which reflects the presence of whales from several feeding areas on a wintering area. Based on our findings, however, an identical mtDNA pattern would be expected between whales off California and Central America: an area that has not yet been sampled for genetic analyses. The genetic and demographic patterns of population structure in the North Pacific appear to be different from the North Atlantic. Current evidence suggests that the majority of humpback whales from almost every feeding area in the North Atlantic gather and 


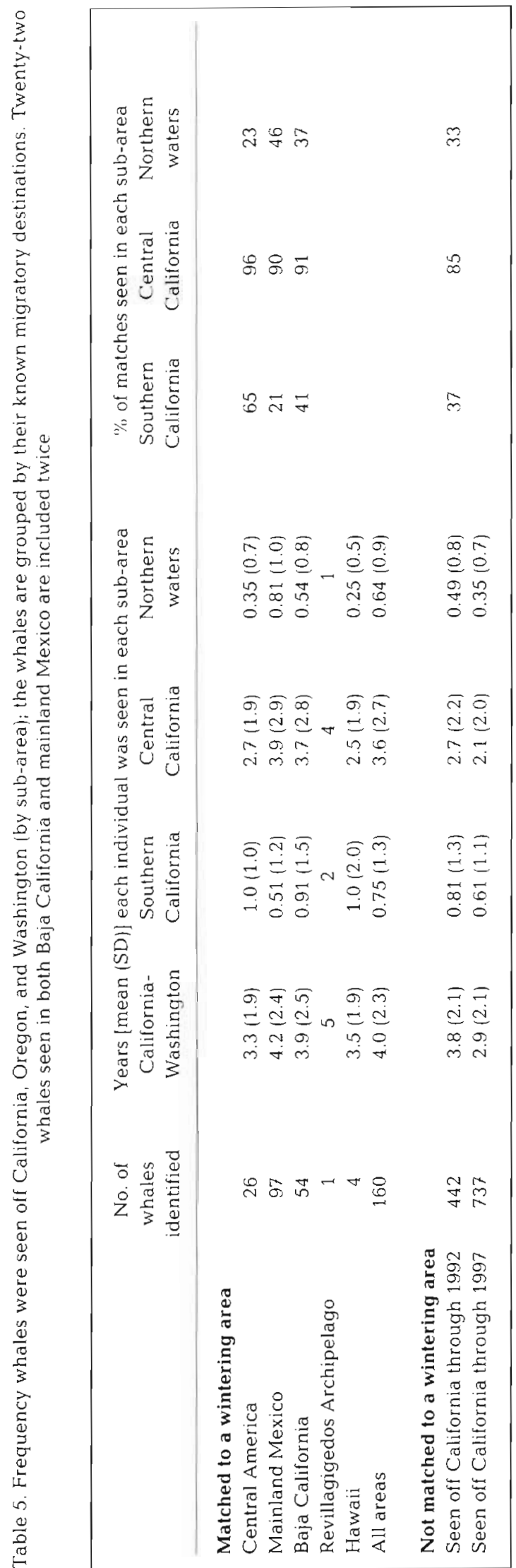

interbreed on a single wintering ground in the West Indies, resulting in a single panmictic population (Mattila et al. 1989, 1994, Clapham et al. 1993, Larsen et al. 1996, Palsboll et al. 1997).

The use of a wintering region only by whales from a single feeding area has not been documented previously for humpback whales. The proportion of whales identified off Central America that were also sighted off California ( $84 \%$ ) was similar to the inter-year match rate $(88 \%)$ within California (the percentage of whales identified each year off California that matched any other year; Calambokidis et al. 1996). While humpback whales from California travel to (or through) several wintering regions, those from Central America appear to have only come from Califormia. While it is clear that whales off Costa Rica use this region to breed and give birth to calves (Rasmussen et al. 1995), the number of whales that inhabit these waters in winter is fairly small, about 100 (Calambokidis 1997). This region is also unique because it is used by southern hemisphere whales during the austral winter (Acevedo \& Smultea 1995, Flórez-González et al. 1998) and is potentially an avenue for gene flow between hemispheres (Baker et al. 1990)

It is not surprising that the whales that travel to Central America, the southernmost wintering region in the North Pacific $\left(8^{\circ} \mathrm{N}\right)$, tend to feed off southern California, the southernmost part of a feeding area that is quite extensive $\left(32\right.$ to $\left.48^{\circ} \mathrm{N}\right)$. Whales from mainland Mexico and Baja California $\left(20^{\circ} \mathrm{N}\right)$ were found more often in the northern waters (northern California to Washington). This pattern of migration suggests a series of partially overlapping migratory corridors and destinations along the coast of North America. Such a pattern could result in a clinal distribution of mtDNA types as suggested by Medrano-González et al. (1995).

Proximity of seasonal habitats, however, does not appear to be a fundamental constraint to migration. Migratory distances of whales for which we have documented transits ranged from 1900 to $5322 \mathrm{~km}$ (straight line, minimum). In the North Pacific, a humpback was observed to travel at least $7900 \mathrm{~km}$ between Japan and British Columbia (Darling et al. 1996). Records of long migratory routes have also been reported in the North Atlantic $(7800 \mathrm{~km}$, Palsboll et al. 1997, Stevick et al. 1998) and South Pacific (8334 km, Stone et al. 1990). Our data show that it is possible for a humpback whale to move from wintering ground to feeding ground in less than a month. The $29 \mathrm{~d}$ migratory transit between central California and southern Baja California is the fastest recorded (in number of days) for a humpback whale in the North Pacific. A faster speed was reported by Gabriele et al. (1996) for a whale that traveled $4400 \mathrm{~km}$ between southeastern Alaska and Hawaii in $39 \mathrm{~d}$ at $4.74 \mathrm{~km} \mathrm{~h}^{-1}$. 
Of the California whales for which the sex was known, the percentage of males re-sighted at wintering regions was more than twice as high as that for females (2.2 males:1 female). Similarly, studies off Hawail have shown that more males than females were identified photographically (Craig \& Herman 1997) Certain whale behaviors on the wintering grounds could affect the sex ratio of whales photographed, which would bias samples taken using this method. Males and females exhibit different affiliations and arrival and departure times (Gabriele 1992). Surface-active groups are often easier to spot and identify photographically, and tend to be composed of mostly males (Clapham et al. 1992, Medrano et al. 1994, Brown \& Corkeron 1995); females with calves tend to raise their flukes less often (Craig \& Herman 1997). Studies using biopsy sampling, however, also suggest that males are, in fact, over-represented on the wintering regions. Whales $(n=180)$ migrating to wintering regions off Australia revealed a ratio of 2.4 males: 1 female, and this ratio suggests that some females do not always complete the migration to tropical waters (Brown et al. 1995). In the North Atlantic, genetic tagging used to determine sex-specific estimates of abundance on the breeding grounds showed that there were $40 \%$ fewer females than males (Palsboll et al. 1997). Samples of whales at North Pacific wintering areas showed a 2.8:1 ratio of males to females ( $n=96$ ), with males outnumbering females in all 5 samples (Baker et al. 1998). It remains to be determined whether this reflects difterential habitat use, different migratory timing, or non-migration by some females, or a combination of the three.

Although previous studies have examined the movement of humpback whales among many regions in the North Pacific, few large-scale comparisons have been reported that allow a quantitative evaluation of the different rates of migratory movement from a feeding area as reported here. Expansion of this approach and the inclusion of data from all known wintering and feeding grounds in the North Pacific in a quantitative comparison would yield a more complete picture of the population structure of humpback whales and the complexities of their migrations

Acknowledgements. Funding for this comparison and the California research was from the Southwest Fisheries Science Center ISWFSC), National Marine Fisheries Service. Additional support for the photo-identilucation research came from the Olympic Coast, Gulf of the Farallones, Monterey Bay and Channel Islands National Marine Sanctuaries, the ATOC Marine Mammal Research Program (funded through the University of California-Santa Cruz by the Office of Naval Research and the Strategic Environmental Assessment Programl and private donors. We thank all those who participated in the photo-irlentification work, especially D. Bockus,
P. Bloedel, T Chandler, D. Claridge, J. C. Cubbage, J. Evenson, J. Quan and L. Schlender. Photographs were provided by many people including N. Black, M. Hansen, P. Howorth, C. Keiper, T. Kieckhefer, E. Martin, R. Smith and researchers at the SWFSC. Additional support was provided by the Channel Islands Natıonal Marine Sanctuary, Bodega Marine Laboratory, Oceanic Society Expeditions, Elderhostel, Drake Bay Wilderness Camp. Fred Benko, the Wallis Foundation and Shearwater Journeys. Jay Barlow (SWFSC) served as the COTR and provided helpful advice. E. McManus, K. Flynn and A. Randle assisted with the photographic comparison This manuscript was improved by Phil Clapham and 3 other anonymous reviewers. This project would not have been possible without the collaboration of many researchers who generously agreed to provide their data. Organizations supporting these researchers included Lniversidad Autonoma de Baja California Sur, Universidad Nacional Autónoma de México, Center for Whale Research, Kewalo Basin Marne Mammal Laboratory (University of Hawaji), West Coast Whale Research Foundation and WWF-Japan.

\section{LITERATURE CITED}

Acevado A, Smultea MA (1995) First records of humpback whales including calves at Golfo Dulce and Isla de Coco, Costa Rica, suggesting geographical overlap of northern and southern hemisphere populations. Mar Mamm Sci 11. $554-560$

Alvarez C, Aguayo A, Rueda R, Urbán J (1990) A note on the stock size of humpback whales along the Pacific coast of Mexico. Rep Int Whal Comm (Spec Issue) 12:191-193

Baker CS, Herman LM, Perry A, Lawton WS, Straley JM, Straley JH (1985) Population characteristıcs and migration of summer and late-season humpback whales (Megaptera novaeangliae) in southeastern Alaska. Mar Mamm Sci 1. $304-323$

Baker CS, Herman LM, Perry A, Lawton WS, Straley JM, Wolman AA, Kaufman GD, Winn HE, Hall JD, Reinke JM, Ostman $J$ (1986) Migratory movement and population structure of humpback whales (Megaptera novaeangliae) in the central and eastern North Pacific. Mar Ecol Prog Ser 31:105-119

Baker CS, Palumbi SR, Lambertson RH, Weinrich MT, Calambokidis J, O'Brien SJ (1990) Influence of seasonal migratuon on geographic distribution of mitochondrial DNA traplotypes in humpback whales. Nature Lond 344 : $238-240$

Baker CS, Lambertson RH, Weinrich MT, Calambokidis J, Early G, O'Brien SJ (1991) Molecular genetic identification of the sex of humpback whales (Megaptera novaeangliae). In: Hoelzel R (ed) Genetic ecology of celaceans. Rep Int Whal Comm (Spec Issue) 13:105-111

Baker CS, Slade RB, Bannister JL, Abernethy RB, Weinrich MT, Lien $J$, Urban-R $J$, Corkeron $P$, Calambokidis J, Vasquez O. Palumbi SR (1994) Hierarchical structure of mitochondrial DNA gene flow among humpback whales. world-wide. Mol Ecol 3:313-327

Baker CS, Medrano-Gonzalez L. Calambokjdis J, Perry A,

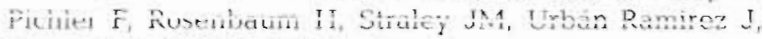

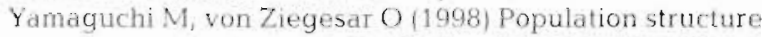
of nuclear and milochondrial DNA variation among humpback whales in the North Pacific. Mol Ecol 7:695-708

Barlow J (1994) Abundance of large whales in California coastal waters: a comparison of ship surveys in 1979/80 and in 1991. Rep Int Whal Comm 44:399-406

Barlow J (1995) The abundance of cetaceans in California 
waters. Part I: Ship surveys in summer and fall 1991. Fish Bull 93:1-14

Brown MR, Corkeron P (1995) Pod characteristics of migrating humpback whales (Megaptera novaeangliae) off the east Australian coast. Behaviour 132:163-179

Brown MR, Corkeron P, Hale PT, Schultz KW, Bryden MM (1995) Evidence of sex-segregated migration in the humpback whale (Megaptera novaeangliae). Proc R Soc Lond Biol Sci 259:229-234

Calambokidis J (1997) Humpback whales and the CaliforniaCosta Rica connection. Whales. J Ocean Soc Fall 4-10

Calambokidis J, Steiger GH (1995) Population assessment of humpback and blue whales using photo-identification from 1993 surveys off California. Final report to Southwest Fisheries Science Center, La Jolla, CA

Calambokidis J, Cubbage JC, Steiger GH, Balcomb KC, Bloedel P (1990) Population estimates of humpback whales in the Gulf of the Farallones, California. Rep Int Whal Comm (Spec Issue) 12:325-333

Calambokidis J, Steiger GH, Evenson JR, Flynn KR, Balcomb $\mathrm{KC}$, Claridge DE, Bloedel $\mathrm{P}$, Straley JM, Baker CS, von Ziegesar O, Dahlheim ME, Waite JM, Darling JD, Ellis G, Green GA (1996) Interchange and isolation of humpback whales off California and other North Pacific feeding grounds. Mar Manm Sci 12:215-226

Cerchio S (1998) Estimates of humpback whale abundance off Kauai, 1989 to 1993: evaluating biases associated with sampling the Hawaiian Islands breeding assemblage. Mar Ecol Prog Ser 175:23-34

Clapham PJ, Palsboll PJ, Mattila DK, Vásquez O (1992) Composition and dynamics of humpback whale competitive groups in the West Indies. Behavior 122:182-194

Clapham PJ, Mattila DK, Palsboll PJ (1993) High-latitudearea composition of humpback whale competitive groups in Samana Bay: further evidence for panmixis in the North Atlantic population. Can J Zool 71:1065-1066

Craig AS, Herman LM (1997) Sex differences in site fidelity and migration of humpback whales (Megaptera novaeangliae) to the Hawaiian Islands. Can J Zool 75:1923-1933

Darling JD (1991) Humpback whales in Japanese waters, Fluke Identification Catalogue 1987-1990. Report for World Wildlife Fund for Nature Japan, Tokyo, by West Coast Whale Research Foundation, Vancouver

Darling JD, Cerchio S (1993) Movement of a humpback whale (Megaptera novaeangliae) between Japan and Hawaii. Mar Mamm Sci 9:84-89

Darling JD, Jurasz CM (1983) Migratory destinations of North Pacific humpback whales (Megaptera novaeangliae). In: Payne R (ed) Communication and behavior of whales. Westview Press, Boulder, CO, p 359-368

Darling JD, McSweeney DJ (1985) Observations of the migrations of North Pacific humpback whales (Megaptera novaeangliae). Can J Zool 63:308-314

Darling JD, Mori K (1993) Recent observations of humpback whales (Megaptera novaeangliae) in Japanese waters off Ogasawara and Okinawa. Can J Zool 71:325-333

Darling JD, Calambokidis J, Balcomb KC, Bloedel P, Flynn K, Mochizuki A, Mori K, Sato F, Suganuma H, Yamaguchi M (1996) Movement of a humpback whale (Megaptera novaeangliae) from Japan and British Columbia and return. Mar Mamm Sci 12:281-287

Flórez-González L, Capelía AJ, Haase B, Bravo GA, Félix F, Gerrodette $T$ (1998) Changes in winter destinations and the northernmost record of southeastern Pacific humpback whales. Mar Mamm Sci 14:189-196

Gabriele CM (1992) The behavior and residence characteristics of reproductive classes of humpback whales (Mega- ptera novaeangliae) in the Hawaiian Islands. MA thesis, University of Hawaii, Kewalo Basin Marine Mammal Laboratory, Honolulu

Gabriele CM, Straley JM, Herman LM, Coleman RJ (1996) Fastest documented migration of a North Pacific humpback whale. Mar Mamm Sci 12:457-464

Herman LM, Antinoja RC (1977) Humpback whales in the Hawailan breeding waters: population and pod characteristics. Sci Rep Whales Res Inst 29:59-85

Katona SK, Baxter B, Brazier O, Kraus S, Perkins J, Whitehead $\mathrm{H}$ (1979) Identification of humpback whales by fluke photographs. In: Winn HE, Olla B (eds) The behavior of marine animals, Volume 3: Cetaceans. Plenum Press, New York, p 33-44

Kellogg $R$ (1929) What is known about the migrations of some of the whalebone whales. Annual Report for 1928, Smithsonian Institution, Washington, DC, p 467-494

Ladrón de Guevara P P (1995) La ballena jorobado, (Megaptera novaeangliae) (Borowski 1781) en la Bahia de: Banderas, viayarit-Jalisco, México (Cetacea: Balaenopteridae). Thesis, Facultad de Ciencias, Universidad Nacional Autónoma de México, Mexico City

Larsen AH, Sigurjónsson J, Oien M, Víkıngsson G, Palsboll PJ (1996) Population genetic analysis of nuclear and mitochondrial loci in skin biopsies collected from central and northeastern North Atlantic humpback whales (Megaptera novaeangliae): population identity and migratory destinations. Proc R Soc Lond Biol Sci 263:1611-1628

Mattila DK, Clapham PJ, Katona SK, Stone GS (1989) Population composition of humpback whales, Megaptera novaeangliae, on Silver Bank, 1984. Can J Zool 67:281-285

Mattila DK, Clapham PJ, Vasquez O, Bowman RS (1994) Occurrence, population composition, and habitat use of humpback whales in Samana Bay, Dominican Republic. Can J Zool 72:1898-1907

Medrano L, Salinas M. Salas I, Ladrón de Guevara P, Aguayo A, Jacobsen J, Baker CS (1994) Sex identification of humpback whales, Megaptera novaeangliae, on the wintering grounds on the Mexican Pacific Ocean. Can J Zool 72:1171-1174

Medrano-González L, Aguayo-Lobo A, Urbán-Ramirez J, Baker CS (1995) Diversity and distribution of mitochondrial DNA lineages among humpback whales, Megaptera novaeangliae, in the Mexican Pacific Ocean. Can J Zool $73: 1735-1743$

Nishiwaki $M$ (1959) Humpback whales in the Ryukyuan waters. Sci Rep Whales Res Inst 14:49-87

Palsboll PJ, Allen J, Bérubé M, Clapham PJ, Feddersen TP,

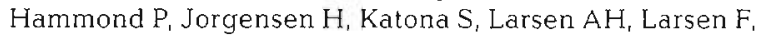
Lien J, Mattila DK, Sigurjónsson J, Sears R, Smith T, Sponer R, Stevick P, Oien N (1997) Genetic tagging of humpback whales. Nature Lond 388:767-769

Perry A, Mobley JR Jr, Baker CS, Herman LM (1988) Humpback whales of the central and eastern Pacific. A catalog of individual identification photographs. University of Hawaii Sea Grant Program, Honolulu

Perry A, Baker CS, Herman LM (1990) Population characteristics of individually identified humpback whales in the central and eastern North Pacific: a summary and critique. Rep Int Whal Comm (Spec Issue) 12:307-318

Rasmussen K, Steiger GH, Calambokidis J (1995) Evidence of a humpback whale wintering area in Costa Rica. In: Abstracts of the Eleventh Biennial Conference on the Biology of Marine Mammals, Orlando. Society for Marine Mammalogy, Lawrence, KS, p 49

Smith TD, Allen J, Clapham PJ, Hammond PS, Katona S, Larsen F, Lien J, Mattila D, Palsboll PJ (1999) An oceanbasin-wide mark-recapture study of the North Atlantic 
humpback whale (Megaptera novaeangliae), Mar Mamm Sci 15:1-32

Steiger GH, Calambokidis J, Sears R, Balcomb KC, Cubbage JC (1991) Movement of humpback whales between California and Costa Rica. Mar Mamm Sci 7:306-310

Stevick PT, Oien N, Mattila DK (1998) Migration of a humpback whale (Megaptera novaeangliae) between Norway and the West Indies. Mar Mamm Sci 14:162-166

Stone GS, Flórez-González L, Katona S (1990) Whàle migration record. Nature Lond $346: 705$

Tomilin AG (1957) Mammals of the USSR and adjacent countries, Vol 9. Akademii Nauk SSSR, Moscow (translated by the lsrael Program for Scientıfic Translations, Jerusalem, 1967)

Editorial responsibility: Otto Kinne (Editor),

Oldendorl/Luhe, Germany
Uchida S, Higashi N, Takemura A (1993) Prelıminary report of humpback whale of Okiniwa, Japan. IBI Reports, International Marine Biological Research Institute, Kamogawa, p $57-67$

Urbán J, Aguayo A (1987) Spatial and seasonal distribution of the humpback whale, Megaptera novaeangliae, in the Mexican Pacific. Mar Mamm Sci 3:333-344

Urbán J, Balcomb KC. Alvarez C, Bloedel P, Cubbage J, Calambokidis J, Steiger GH, Aguayo A (1987) Photo-identification matches of humpback whales Megaptera novaeangliael between Mexico and central Califorma. Abstracts of the Seventh Biennial Conference on the Biology of Marine Mammals, Miami. Society for Marine Mammalogy, Lawrence, KS, p 72

Submitted: December 7. 1998; Accepted: July 12, 1999 Proofs received from author(s): January 3, 2000 